University of Massachusetts Amherst

ScholarWorks@UMass Amherst

National Center for Digital Government

Centers and Institutes

$10-1-2003$

\title{
Bureaucratic Networks or Networked Bureaucracies? Knowledge Sharing in ICT-Enabled Innovation Projects
}

Maria C. Binz-Scharf

Harvard University

Follow this and additional works at: https://scholarworks.umass.edu/ncdg

Part of the Computer Sciences Commons, Political Science Commons, and the Science and Technology Studies Commons

Binz-Scharf, Maria C., "Bureaucratic Networks or Networked Bureaucracies? Knowledge Sharing in ICT-Enabled Innovation Projects" (2003). National Center for Digital Government Working Paper Series. 20.

Retrieved from https://scholarworks.umass.edu/ncdg/20

This Research, creative, or professional activities is brought to you for free and open access by the Centers and Institutes at ScholarWorks@UMass Amherst. It has been accepted for inclusion in National Center for Digital Government by an authorized administrator of ScholarWorks@UMass Amherst. For more information, please contact scholarworks@library.umass.edu. 


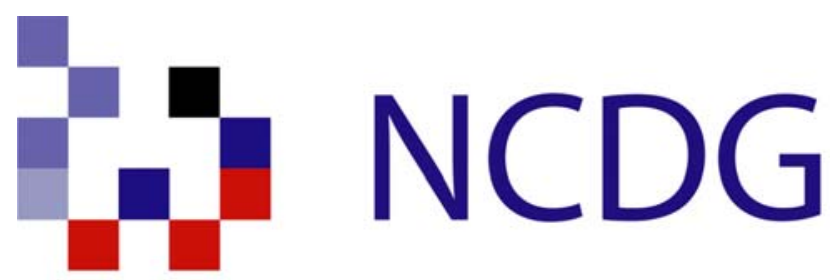

National Center for Digital Government

\title{
"Bureaucratic Networks or Networked Bureaucracies? Knowledge Sharing in ICT-Enabled Innovation Projects”
}

\author{
Maria C. Binz-Scharf \\ Harvard University \\ maria_scharf@harvard.edu
}

NCDG Working Paper No. 03-012

Submitted 10/01/2003

This material is based upon work supported by the National Science Foundation under Grant Number 0131923. Any opinions, findings, conclusions or recommendations expressed in this material are those of the author(s) and do not necessarily reflect the views of the National Science Foundation (NSF). 


\begin{abstract}
This paper examines knowledge sharing processes in digital government projects (DGPs). Although knowledge sharing processes are a central feature of the functioning of government, they have received little attention in the literature. The importance of knowledge sharing has become even more evident with the rise of digital government initiatives, as these have a networking effect on bureaucracies. With multiple agencies and multidisciplinary knowledge coming together, it is necessary to combine and reconnect the required knowledge. Based on empirical data from four DGPs in Switzerland and the United States, a theoretical model for knowledge sharing in DGPs is proposed. The model ties together processes and content of knowledge sharing through two task dimensions, each of them subdivided into two phases: (1) Conception and implementation of the project, and (2) Exploration and exploitation of knowledge. I show that the implementation of DG requires a balanced mix of exploration and exploitation of knowledge, where exploration is more important in the conceptual phase, and exploitation becomes more fruitful in the implementation phase. I found that different configurations of knowledge networks in DGPs are related to different stages in the advancement of the project: DGPs rely on sparse networks during the conceptual phase of the project, and tend to employ teams or tightly-bound groups when the project moves towards implementation. The study concludes with implications for research and practice.
\end{abstract}


Bureaucratic Networks or Networked Bureaucracies?

Knowledge Sharing in ICT-Enabled Innovation Projects

The possibilities the Internet affords have grown to be ever more important for government agencies in recent years. With tasks continuously growing in complexity and with more decentralized structures, Internet-related technologies have become a necessity for government agencies to function successfully. In addition, the managerial mindset created by public sector reforms such as the National Performance Review (NPR) in the United States (National Performance Review, 1993; Osborne \& Gaebler, 1992) or the New Public Management (NPM) in Europe (Barzelay, 1992, 2001; Schedler, 1995) demanded that citizens' interests be at the core of public administration's attention, advocating a customer orientation comparable to the private sector. Together with the information society as a driving force, this has led politicians and government officials the world over to make large investments in new information and communication technologies (ICT) in order to provide public services online.

Generally, the introduction of these new technologies takes place in the form of a specific project (referred to as a “ digital government project” in this study). These project groups may assume any form between the two extremes of a tightly-knit work team with clear boundaries, whose members were recruited specifically for the project, to a loosely-bound group of individuals spread across various agencies, who participate in the project on a voluntary basis. The success of a digital government project (DGP) depends upon a mix of external and internal factors. In terms of factors external to an agency, political endorsement and constituent satisfaction are especially important, whereas significant internal factors are the government officials' ability to manage innovation, and knowledge sharing within the agencies. This study focuses on the last, examining how knowledge is shared in DGPs: how do public managers decide what to include and what to exclude in a project? How do they attribute priorities to various activities? What sources inform these decisions? How is their communication network structured? 
Significance of the study: The importance of knowledge

The rising importance of knowledge has been used to characterize post-industrialist societies (Bell, 1973; Drucker, 1993; Habermas, 1971, 1979). Knowledge, it is argued, is a principal economic resource. Unlike traditional factors of production (such as land or equipment) to which knowledge is often compared, knowledge resides within individuals, making it an intangible asset, and therefore difficult to acquire and share. In post-industrialist societies in general and in government agencies in particular, knowledge acquisition and sharing is one of the most important social processes.

Knowledge sharing processes are a central feature of the functioning of government, but, with very few exceptions (cf. Blau, 1963), they have received surprisingly little attention in the literature. The importance of knowledge sharing has become even more evident with the rise of digital government (DG) initiatives, as these have a networking effect on bureaucracies. The fact that individuals with differing skill sets and from different organizational units work on a common task creates a network that coexists with the functional subdivision of tasks within the organization. Common tasks by their nature require knowledge sharing in order to be fulfilled successfully. With multiple agencies and multidisciplinary knowledge coming together, it is necessary to combine and reconnect the required knowledge.

Knowledge sharing in the public sector confronts some specific challenges, such as budget restrictions; data privacy and confidentiality, and related security issues, which, due to mandatory regulations, are a top priority for government; as well as a traditionally rigid hierarchical structure, which render the transition of bureaucracies toward networks difficult (Agranoff \& McGuire, 2001; Bardach, 1999; Fountain, 1999; Lazer, 2002).

\section{The "digital government" phenomenon}

Digital government refers to the potential to deliver public services online in a customeroriented fashion. Digital government initiatives comprise a wide range of IT-enabled applications which require a new way of thinking about government processes in order to achieve efficiency gains by taking advantage of the possibilities that new technologies offer. 
Whereas the term “digital government”, or e-government, was diffused to the general public with a special report of the Economist in June 2000 (Economist, 2000), research on ICTinduced changes in government goes back a long way (Adler \& Borys, 1996; Gupta, Dirsmith, \& Fogarty, 1994; Lenk, 1997; Reinermann, Fiedler, Grimmer, Lenk, \& Traunmüller, 1988; Tsagarousianou, Tambini, \& Bryan, 1998). Clearly, the Internet denotes a tipping point in history, and government has played an important role in shaping it. But what is truly fascinating is the challenge that this universal phenomenon represents to governments as they try to meet the needs of citizens in an information age not by simply automating existing processes, but by innovating and redesigning processes (Bellamy \& Taylor, 1998; Lenk, 1997) and, even more radically, by completely transforming institutions (Fountain, 2001).

\section{Paving the way: Public sector reforms}

It can be argued that public sector reforms laid the groundwork for DG initiatives (Schedler \& Scharf, 2001), emphasizing the importance of efficiency gains, attempting to introduce market-like principles into government, most visibly expressed in a shift from input to output orientation as well as an orientation toward the customers of government (Barzelay, 1992; Osborne \& Gaebler, 1992). There is, however, at least one important difference between the driving forces of these reforms and DG initiatives: whereas public sector reforms are strategydriven and originate chiefly within government, DG is driven more by outside pressures such as the information society (Schedler \& Summermatter, 2002).

The DGPs examined in this study are located in two different countries: Switzerland and the United States. Both countries experienced public sector reforms in the 1990's, and although similar policy concepts have been employed, one should bear in mind that they carry different operational and institutional meanings in European and American settings (Toonen \& Raadschelders, 1997). The nature and content of American managerial reforms in the context of the Clinton-Gore Reinventing Government program (National Performance Review, 1993) differ from the Swiss version of New Public Management (NPM) in that Swiss reforms are characterized by stronger political control processes (the general basis for state action in 
Switzerland is a specialized public law), and the emphasis lies on outcomes rather than outputs (Schedler, 1998).

One characteristic the US American and European interpretations of public sector reforms seem to have in common is their focus on explicit information transactions along formal reporting structures rather than on informal knowledge sharing within and across governments. Only recently public management scholars have begun to acknowledge the importance of the latter, which Agranoff \& McGuire call “management’s hidden dimensions” (1999), stating that nonroutine "[i]nformation transactions are the lifelines between governments as parties attempt to make programs work,” (Agranoff \& McGuire, 1999:357). Similarly, Lynn (1996) calls for network theory to complement traditional theories of intra- and interorganizational relationships. The present study's endeavor is to strengthen and reinforce these claims by examining the structure and content of knowledge networks that exist within and across agencies and are directed at implementing innovation projects. The projects examined in this dissertation represent a good domain to study networked government since DGPs by their nature require that organizational boundaries be crossed, bringing together multiple actors with multidisciplinary knowledge, which needs to be pooled in order to successfully fulfill the project objectives.

\section{Theoretical foundations}

Above I have made an argument for the crucial importance of knowledge sharing in digital government projects (DGPs). DGPs bring together individuals from different organizational units, with different skill sets, and different mental models, to work on a common goal - the implementation of the project. The following elements of knowledge sharing are particularly important in this context: (1) Modes of knowledge sharing. Knowledge can be imitated, copied, or transferred through communication (Zander \& Kogut, 1995), each mode yielding different results according to the actors involved - individuals, groups, the organization, and other organizations; (2) Influencing factors of knowledge sharing. Experience, trust, motivation, and the difficulty of knowledge transfer significantly influence whether and how effectively knowledge is shared; and (3) Coordination mechanisms of knowledge. Knowledge sharing is different in hierarchies, routines, networks, and groups, mechanisms which coexist in all DGPs of this study. 


\section{Knowledge sharing}

Over the past decade, scholars from a variety of disciplines have produced a considerable volume of literature on knowledge sharing. Recent issues of the Strategic Management Journal (Spender \& Grant, 1996) and Organizational Behavior and Human Decision Processes (Argote, Ingram, Levine, \& Moreland, 2000) focused on knowledge sharing in groups and organizations, reflecting the multiplicity of perspectives from which knowledge sharing has been studied. For organizational researchers, a predominant perspective on knowledge sharing has been to understand the modes through which knowledge is shared. Knowledge resides in people, products and procedures of the organization; and this knowledge can be imitated, copied, or transferred through communication (Zander \& Kogut, 1995). Imitation of knowledge is difficult because, as Reed \& DeFillippi (1990) put it, “there is a fundamental difference between having information and understanding it” (Reed \& DeFillippi, 1990:94). Szulanski (1996) used von Hippel's (1994) concept of 'stickiness' to explain why knowledge is not shared within an organization, claiming the barriers to imitation to be the recipient's lack of absorptive capacity (the ability to exploit outside resources of knowledge), and causal ambiguity (the lack of transparency about what the factors of production are and how they interact during production). At the organizational level, probably the most frequently discussed mode for effective knowledge sharing is organizational learning. The term was popularized by Argyris \& Schön (1978), although also studied by March \& Simon (1958) and Cyert \& March (1963). Argyris \& Schön defined organizational learning as the ability of an organization to detect and correct error. They developed the concept of single-loop learning to identify the process through which organizations detect and correct error within existing definitions of norms, policies, and objectives. Single-loop or lower-level learning involves the gradual improvement of organizational practices and routines (Argyris \& Schön, 1978; Nelson \& Winter, 1982). Doubleloop or higher-level learning is the process through which "error is detected and corrected in ways that involve the modification of an organization's underlying norms, policies, and objectives,” (Argyris \& Schön, 1978:3). In other words, double-loop learning involves learning how to learn (Cummings, 2002). 
Another important influence on knowledge processes is given by the factors that affect the smoothness or difficulty of knowledge sharing. A predominant aspect lies in the nature of the knowledge itself: whether the knowledge being transferred is tacit or articulate has an important impact on the ease of transfer (Zander, 1991) But even the sharing of articulate knowledge can often pose difficulties because of the recipient's lack of absorptive capacity and causal ambiguity (Gabriel Szulanski, 1996), and therefore its sharing can be costly (Grant, 1996). Yet, it can be costly if critical knowledge is not shared. Hoopes \& Postrel (1999) defined the errors possible only because knowledge was not shared as 'glitches'. Szulanski (2000) termed the lack of knowledge sharing as “one of the most surprising lessons” (G. Szulanski, 2000:10) from the recent scholarly interest in knowledge sharing: the fact that an individual somewhere in the organization possesses potentially valuable knowledge does not necessarily mean that somebody else of the same organization, or the organization itself, benefits from this knowledge. The reason for this is that transfers of knowledge can be difficult, an aspect which, "when acknowledged [by scholars], [...] is seen as an anomaly rather than as a characteristic feature of the transfer” (G. Szulanski, 2000:10).

So what is it that makes individuals share their knowledge? At the group level, frequently discussed prerequisites for knowledge sharing are trust in the source-recipient relationship (Bouty, 2000; Dirks \& Ferrin, 2001; Edmondson, 1999; Perloff, 1993; Uzzi, 1997; Williams, 2001), and motivation (Guzzo \& Dickson, 1996; Osterloh \& Frey, 2000). Researchers in the field of social psychology have used the notion of shared mental models to explain knowledge sharing and decision making (Cannon-Bowers, Salas, \& Converse, 1993; LanganFox, Code, \& Langfield-Smith, 2000; Mohammed \& Dumville, 2001). Mental models are organized knowledge structures that allow individuals to predict and explain the behavior around them, and to predict what is likely to occur next (Rouse \& Morris, 1986). Shared mental models positively affect team process and performance, but the magnitude of the impact depends on the mental model being shared (Mathieu, Heffner, Goodwin, Salas, \& Cannon-Bowers, 2000). Even if individuals have conflicting preferences for reaching a decision, but share similar mental models of the decision context, they are likely to come to an agreement (Richards, 2001). On the other hand, the differentiation of roles in a team leads to less knowledge transfer and a decline in shared mental models over time (Levesque, Wilson, \& Wholey, 2001). 
Knowledge and technology. Scholarly interest in the causal relationship between technology and knowledge processes predates the invention of computers. The prominence of the topic, however, has grown enormously with the event of computer technology, as Blau \& Schönherr (Blau \& Schönherr, 1971) describe: “[m]achine technology has played a major role in many organizations for a long time, be they manufacturing concerns or armies, but its significance in government bureaus and other white-collar offices has been minor unto quite recently. The invention and production of computers changed the situation drastically, though conventional data-processing equipment had already brought about some lesser changes earlier. Even if computers are essentially used for routine accounting and record-keeping functions, [...] automation basically alters many operations.” (Blau \& Schönherr, 1971:50). Information technologies differ substantially from traditional technologies: in addition to affecting the production of goods and services, IT has the potential to affect the functioning of coordination and communication within an organization and between organizations (Fountain, 2001). Hence, technology can be supportive of more efficient coordination and communication processes, but it can also stand in the way of efficiency and effectiveness when existing technologies, such as legacy information systems, determine the choice of new technologies, thus creating a path dependence (Fountain, 2001).

In the relationship between technology and the individual, skill acquisition is important (Goodman, Griffith, \& Fenner, 1990): new technologies are generally more complex than traditional technologies, and are provided by multiple vendors. This not only requires different areas of expertise from different parts of the organization, but more importantly, there is a need to integrate those different sources of knowledge about skills in order to make the technological system work as a whole. In addition, new technologies tend to involve various levels and parts of the organization, requiring more coordination efforts by multi-skilled people who work across boundaries. Therefore, the focus shifts "from acquisition of knowledge in a single role to knowledge across different roles,” (Goodman et al., 1990:57). Eventually, changes in work roles and their relations affect the structure of an organization's social networks (Barley, 1990). McDermott (1999) argues that recent developments in IT have inspired organizations to think about new ways of sharing knowledge, only then to discover that knowledge sharing is more 
dependent on building human communities (or functioning within a social network) than IT. In a similar vein, Roberts (2000) sees IT as a facilitator for knowledge transfer. However, IT has very little impact on a firm's production process when it comes to the transfer of tacit knowledge: "the transfer of know-how requires a process of show-how. Face-to-face demonstration and the social interaction involved enable the sharing of skills and the establishment of mutual understanding and trust.” (Roberts, 2000: 440).

\section{Coordination mechanisms of knowledge}

Scholars of many disciplines have studied formal and informal organizational structures as coordination mechanisms for knowledge processes. The role of hierarchies as opposed to markets, and increasingly the notion of networks, have been discussed as allocation mechanisms for knowledge (Podolny \& Page, 1998; Powell, 1990). The main distinguishing factors of those different allocation forms are the locus of authority and control, and consequently the different ability to either transfer or develop tacit or explicit knowledge efficiently. Organization design theory suggests that the information capacity of coordination mechanisms should match information requirements of the task at hand (Galbraith, 1973). Generally, the literature distinguishes three organizational forms with regard to the analysis of knowledge processes: markets, hierarchies, and networks (Bruce Kogut \& Zander, 1996; Nault, 1998; Podolny \& Page, 1998; Powell, 1990). In a hierarchy approach of allocation, knowledge is readily available in the organization, as the organization has complete control over the knowledge process.

Bureaucracies rely on rationalized knowledge ${ }^{i}$ that is collected mostly in databases, reports, or handbooks (Weiss, 1998). In line with Weber's ([1921]1968) depiction of the ideal-type bureaucracy, individuals are arranged in a bureaucracy to carry out specialized tasks, based on explicit rules and procedures (Cohen \& Bacdayan, 1994; Cyert \& March, 1963). In this formal organization mechanism, knowledge is likely to be structured with explicit rules of action. A recent network theory-based explanation for the theory of the firm argues that organizations have advantages over markets because they can mobilize social capital embedded in human relations in order to create intellectual capital (Bouty, 2000; Nahapiet \& Ghoshal, 1998).

Prior research has shown that, while hierarchies are generally efficient for carrying out specialized tasks based on explicit rules and procedures (Arrow, 1974; Cohen \& Bacdayan, 
1994; Cyert \& March, 1963; Weber, [1921]1968; Weiss, 1998; Williamson, 1975), informal networks more efficiently diffuse, utilize and integrate knowledge (Brown \& Duguid, 2001; Grant, 1996; Grant \& Baden-Fuller, 1995; B. Kogut, 2000; Bruce Kogut \& Zander, 1996; Nault, 1998; Podolny \& Page, 1998; Powell, 1990). Kogut \& Zander (1992) propose several coordination mechanisms for knowledge transfer operating on different organizational levels. They argue that transfer of knowledge from an individual to a group level occurs through the development of unique language or code which allows group members to learn who knows what and to coordinate their activities. On the organizational level the transfer of knowledge within the same function (horizontally) is realized by boundary spanners. At the same time, a vertical transfer of knowledge among different organizational functions relies on the use of higher-order organizing principles through formal and informal structures. Coordinating different units to share their knowledge is critical to enhance an organization's capabilites (Bruce Kogut \& Zander, 1996). Similarly, Tsai (2002) suggests that knowledge sharing within a multiunit organization requires both formal and informal structures as coordination mechanisms. Whereas Tsai differentiates between formal hierarchical structure and informal lateral relations, Gittell (2002) proposes a set of coordination mechanisms without specifying their formal or informal character: routines, boundary spanners, and team meetings.

The model in figure 1 shows the causal relationships of knowledge sharing in DGPs. It attempts to bridge between the organizational context, i.e. structures influencing knowledge sharing within the group (coordination mechanisms); processes, i.e. the interaction between group members given their interdependencies (group dynamics); and the content of the knowledge that is being shared. Formal coordination mechanisms, e.g. hierarchies, are more likely to have an impact on structural interdependencies among the group members, such as relations that are linked to existing structures. On the other hand, informal coordination mechanisms, such as social networks, are prone to having a stronger influence on cognitive interdependencies, which refer to informal social communication. Both formal and informal mechanisms act upon functional interdependencies, i.e. goals and tasks that the group members have in common. Finally, all types of interdependencies form the interactions between the group members, which are at the basis of knowledge sharing processes within the group. For the purpose of this study, I examine hierarchy as a formal coordination mechanisms of knowledge; 
and two informal coordination mechanisms, social networks and group dynamics. These coordination mechanisms of knowledge are discussed in greater detail below.

Figure 1: Causal model of knowledge sharing in DGPs

Hierarchical structures. Formal hierarchical structures are one way to coordinate knowledge processes in complex organizations comprised of multiple specialized units (Tsai, 2002). In hierarchies, communication occurs in the context of an employment relationship, and relationships are important, although the patterns of interaction are most strongly determined by an individual's position within the formal hierarchical structure (Powell, 1990). The analysis of hierarchical structure as a coordination mechanism of communication has played an important role in organizational research. Exemplary elements of formal organizational structure are formalization, specialization, and centralization (van de Ven, 1976). Standardization is a central characteristic of hierarchical structures, specifying tasks, standard operating procedures, rules, and policies to coordinate the performance of specialized roles within an organizational component (van de Ven, 1976). Role specialization refers to the subdivision of tasks among employees (van de Ven, 1976), which renders work tasks highly interdependent in hierarchical structures (Powell, 1990). Another traditionally mentioned feature of hierarchical structure is centralization based on an authority structure. From a coordination perspective, under certain circumstances a centralized structure can be beneficial to decision-making processes (Williamson, 1975): if the requisite information-processing and decision-making talents are not widely distributed, it is more efficient to reserve "the central information collection and decisionmaking position to the one or few individuals who have superior information processing capacities and exceptional oratorical and decision-making skills,” (Williamson, 1975:52). On the other hand, centralization could prevent a unit manager from exercising sufficient discretion in dealing with the demands of his or her task environment. This might be the cause for inefficiencies, as the knowledge transfer from from the individual unit to the head of the agency is inclined to error and therefore slows decision-making (Poppo, 1995). In addition, centralization can reduce the initiatives that a unit might take in inter-unit exchange, thus not being interested in sharing knowledge with other units unless required to do so by a higher authority (Tsai, 2002). 
Social networks. Digital government projects have a networking effect on bureaucracies. The fact that individuals with differing skill sets and from different organizational units work on a common task creates a network that coexists with the functional subdivision of tasks within the organization. Even in the most bureaucratic settings, informal social relations are an important source of task advice (Blau, 1963; Dalton, 1959; Kanter, 1977), and can affect the content and quality of decision-making (Crozier, 1964; Hickson, Hinings, Lee, Schneck, \& Pennings, 1971). The study of organizational social networks has attracted the attention of scholars from different fields for many years (for a review, see McPherson, Popielarz, \& Drobnic, 1992). A social network consists of a finite set of actors and the relations defined on them (Wasserman \& Faust, 1994), and of particular relevance to this study are theories regarding structure and content of these relations. The structure of social networks builds around the positions and roles of the involved actors, and the ties that exist between them. An important distinction in social network theory is made between strong and weak ties, i.e. the frequency or intensity, also termed 'quantity' of ties. Whereas strong ties tend to bind cliques of individuals and primarily convey within-group knowledge, weak ties bridge cliques and are therefore source of new knowledge (Granovetter, 1973). However, knowledge sharing in networks requires strong ties (Dyer \& Nobeoka, 2000; Morten T. Hansen, 1999). In a study on the performance of organizational teams, Ancona \& Caldwell draw together internal and external ties of teams, finding that teams engage in vertical communications aimed at molding the views of top management, and in horizontal communication aimed at coordinating work and obtaining feedback. They show that the type of external communication teams engage in, not just the amount, determines performance.

Of particular interest to this study is the recent concept of knowledge networks (Contractor et al., 2000; M. T. Hansen, 2002; Monge \& Contractor, 2003), indicating that the content of ties between actors consists of some form of knowledge. The location of knowledge within a network of actors varies along a continuum, spanning from knowledge residing with one actor to knowledge distributed among many actors (Farace, Monge, \& Russell, 1977). At the individual level, actors have their own ideas about the distribution of knowledge among actors in the network; i.e. their own cognitive knowledge networks (Contractor et al., 2000). Furthermore, 
knowledge networks are characterized by fluidity of actors and their ties: based on the tasks to be accomplished, their interests, resources, and commitments, actors join or leave a knowledge network. In addition, the ties within a knowledge network are prone to change with evolving tasks, the distribution of knowledge, or changes in the actors' cognitive knowledge networks (Contractor et al., 2000). Lazer (2001) takes the concept of network fluidity further by arguing that the network structure influences individuals and is in turn influenced by them. In a study of a large government agency he found that network elasticity varies according to whether the network is intra- or extraorganizational: while extraorganizational networks are characterized by fluidity, intraorganizational networks tend to be rigid.

Group dynamics. As the majority of decision-making processes concerning the conception and implementation of DGPs take place within the project group, group dynamics play an important role in knowledge sharing. A group is defined here as any number of people who interact with one another, are psychologically aware of one another, and perceive themselves to be a group (Schein, 1980). ${ }^{\text {ii }}$ Knowledge sharing within groups is influenced by the expertise, knowledge, and information that group members bring to the group (Jackson, 1996), and its processes and structures affect a group’s performance (Hackman, 1987; Rulke \& Galaskiewicz, 2000). Furthermore, how knowledge is shared within a group depends on the group’s cultural characteristics (Cox, Lobel, \& McLeod, 1991; Earley, 1994; Ely \& Thomas, 2001; Erez \& Somech, 1996; Gibson, 1999; Larkey, 1996; Watson, Kumar, \& Michaelsen, 1993).

The framework of group dynamics is one that views people as coexisting in groups because of interdependencies that link them together (Lewin, 1948). Lindenberg (1997) discusses why the group-dynamics research traditions, that seemed to promise in the 1960s a synthesis between ethnographic findings (e.g., Homans, 1950) and experimental studies (e.g., Bavelas, 1950), soon fell into specialized strands, which he identifies as functional (see Homans, 1950), cognitive (see Sherif, 1936), and structural (see Cartwright \& Harary, 1956) interdependencies; each with significant but limited success. Lindenberg argues that for these strands to be reintegrated, it is necessary to change from social exchange theory to a theory of production, where exchanges are governed by exigencies of production. Such a theory must 
include a theory of goals and a theory of framing (limited or cognitively framed rationality) that connects goals and functional interdependence with social cognition. Further, as groups are always connected in a production process with other groups, they must be studied as networked entities (Lindenberg, 1997).

The study of functional, cognitive, and structural interdependencies in groups has interested scholars beyond the field of social psychology (Forsyth, 1983). Functional interdependence indicates the interdependence concerning group goals or tasks. This functional interdependence stands at the origin of group formation: Members of a group generally share a common goal or task that cannot be reached by an individual alone (Alderfer, 1977; Hackman, 1987). Cognitive interdependence refers to informal social communication, informal social comparison, and norms. People depend on others for the validation of their beliefs, which they jointly adjust or newly form in groups. In his well-known case study of a federal enforcement agency, Blau (1963) observed consultation among colleagues within the agency. Blau concluded that consultation among colleagues contributed to effective operations in their agency, though at some social cost, as department supervisors required that agents turn to them instead of consulting among colleagues. Regarding social status, Blau observed that members of a group were especially attracted to the colleagues whose abilities they respected, leading to an integrated position of members with "superior competence" (Blau, 1963:156) in the group. Structural interdependence comprises a vast array of structural relations, such as different communication structures according to the group atmosphere, or the existence of cliques within larger groups. For example, March \& Simon (1958) observed the structure of problem-solving processes at the group level. They found that these processes are governed by hierarchically structured programs, which are both procedural (problem goes through a sequence of broad phases, e.g. problem formulation, search for alternatives, evaluation of alternatives, etc.), and substantive (problem is first analyzed in broad terms, then each of its aspects becomes a subproblem to be further analyzed in detail (March \& Simon, 1958:201).

\section{Methodology}

This study combines a qualitative exploratory case study design (Yin, 1994) and a grounded theory approach (Glaser \& Strauss, 1967), with the aim of theory building through the 
comparative analysis of case studies (Eisenhardt, 1989). Although the ideal starting point for theory-building research is to have "no theory under consideration and no hypotheses to test" (Eisenhardt, 1989:536), every researcher brings a number of assumptions to the research task. The theoretical perspective is a statement of these assumptions, and it is reflected in the methodology as it is applied (Crotty, 1998). The interpretivist approach seems particularly wellmatched for this study, since interpretivists argue that human, or social, action is different from the movement of physical objects in that the former is inherently meaningful. Thus, to understand a particular social action (e.g., collaboration), the researcher must be aware of the meanings that form that action. Therefore, in order to be able to state that human action is meaningful, one has to claim either that the action is to a certain extent intentional, or that the meaning of an action can only be understood in terms of the system of meanings to which it belongs (Schwandt, 2000).

Hence, by choosing an interpretivist approach embedded in a constructionist epistemology, the main assumptions that I bring to this study are the following: (1) DGPs are essentially constructed out of a combination of various social actions; (2) by analyzing the meaning of these social actions, I can understand the social processes that shape DGPs; and (3) knowledge sharing in DGPs needs to be interpreted taking into account the institutional and cultural context in which the projects are located.

\section{Data collection}

The data for this study were collected in the period May 2001 - June 2002 during field research at the sites of four DGPs, and after a follow-up email survey sent to these sites in the beginning of 2003. In the field, I conducted open-ended, semi-structured one-on-one interviews with the key persons involved in each project, using an informal list of questions as interview guidelines. I was also allowed to observe several meetings and explore office buildings, and I took field notes on observations, spending between four and seven full working days at each site. Furthermore, I analyzed documents which I received from the interviewees or through official sources. All interviews were recorded on tape and transcribed, totalling over 700 pages of single-spaced interview transcripts. In addition, throughout the study I kept a research journal, taking notes whenever I came across literature, a presentation, or documentation which I deemed 
relevant to my research process. Toward the conclusion of the study, I also conducted a followup network survey to gain a better understanding of the knowledge networks in DGPs in terms of relevant actors and task interdependence structures. I asked all interviewees to whom they give information and from whom they receive information relating to their project, letting them choose from a list of names which had arisen during the interviews, in addition to all the interviewees from each project. Furthermore, they had the possibility to add names that I had not listed. I entered the resulting matrices of communication links into UCINET (Borgatti et al. 2002) and visualized them with NetDraw (Borgatti 2002). The response rate was $93 \%$.

Sampling strategy. The sample for this study consists of four cases. I selected the sample through theory-driven, progressive sampling; i.e. I chose the cases sequentially based on theoretical rather than statistical considerations (Miles \& Huberman, 1994). The cases needed to be comparable, which is why I applied a literal replication strategy (Yin, 1994) for the sites, selecting them based on the same relevant characteristics over time. The sampling parameters were (1) state-level government agencies in economically advanced settings with comparable jurisdictions, and (2) a clearly identifiable digital government project. However, I also used a theoretical replication strategy (Yin, 1994) by (1) selecting cases in two different countries, Switzerland and the United States of America, assuming an influence of the cultural context on knowledge sharing processes; and (2) by selecting cases in different stages of their project, in order to gain a better understanding of the processes. For the informants, I employed a reputational selection strategy, i.e. the instances were chosen on the recommendation of an “expert” or “key informant” (Goetz \& LeCompte, 1984).

\section{Data analysis}

The data interpretation process was carried out simultaneously with the data collection and a review of relevant literatures. This iterative process, of which the causal model presented in above was an intermediate result, is a distinct feature of the grounded theory approach (Glaser \& Strauss, 1967), and it continued until the completion of the project. The general work process of grounded theory revolves around the elements of data collection, analysis, and theory formulation. Grounded theory requires that theory is emergent from the data, but does not see these as separate. Data collection, analysis and theory formulation are regarded as reciprocally 
related, and the approach incorporates explicit procedures to guide this (the 'doubling back-andforth’ procedure; (Strauss, 1987:19). My analysis involved three data coding processes, which partially overlapped: open, axial, and selective coding. During open coding, where data is broken open to identify relevant categories, I examined the interview transcripts line by line (Charmaz, 2000), resulting in an initial list of 160 codes. During the process of discovering categories, I assigned and specified properties for each category. The purpose of axial coding is to reassemble data that were fractured during open coding. The categories that emerged during axial coding are (1) Decision-making processes in DGPs, (2) Modes of knowledge sharing in DGPs, (3) Influencing factors of knowledge sharing, and (4) Coordination mechanisms of knowledge. Finally, selective coding is the “... process of integrating and refining the theory derived" (Strauss \& Corbin, 1990:143). Categories retrieved during open and axial coding are systematically integrated to form a larger scheme, which constitutes the form of theory. Integration is an ongoing process, which occurs over time and results in the discovering of a core category. By pulling the other categories together to form an explanatory whole, the core category represents the main theme of the study. Once a theoretical scheme has been developed from the coding procedures, the theory derived has to be refined, which consists of reviews for internal consistency and logical gaps. Poorly developed categories are saturated through further theoretical sampling. In this study, I developed four core categories along two task dimensions: (1) Conception and implementation of DGPs, and (2) Exploration and exploitation of knowledge.

\section{Findings: Understanding knowledge sharing in DGPs}

To present the findings of my field research, I have chosen a narrative form to communicate the findings, as this technique is particularly suited to convey the richness of values and norms that arises from exploratory case studies (Czarniawska, 1997). Since this richness is also expressed in terms of volume, I selected meaningful quotes out of thousands of pages of codes to illustrate the categories that emerged from the data. As discussed earlier, it is useful to study knowledge sharing in DGPs in terms of its modes, influencing factors, and coordination mechanisms. Elsewhere I have shown that also the nature of decision-making processes in DGPs plays an important role in explaining knowledge sharing (Scharf, 2003). The following categories of data are presented below: (1) modes of knowledge sharing in DGPs; and (2) coordination mechanisms of knowledge. 


\section{Modes of knowledge sharing in DGPs}

The first category addresses the operational aspect of the main research question of this study; i.e. how is knowledge shared in DGPs? I found four main modes of knowledge sharing: (1) Documents and databases, (2) Imitation, (3) Learning, and (4) Meetings.

Documents and databases. Because of the traditional functioning of bureaucracy, one might reasonably assume that knowledge storage and retrieval through documents and databases plays a central role in DGPs. And indeed, this is the case - however, attention needs to be paid to the distinction between information and knowledge, a sharp delineation that individuals in all projects made in terms of usefulness. For example, all DGPs have intranets and access possibilities to databases, and they are used to retrieve routine information. But because in most cases the tasks require complex knowledge rather than routine information, “...people read or write something, then they call or meet somebody to discuss it”. Years ago, in DGP 3 there had been a (failed) attempt to build a knowledge database:

One of the things that my boss actually wanted to do is start building a knowledge management database, so that when people get phone calls, regardless of what agency does the phone call, there is a knowledge management database that they can refer to be able to better help point that customer in the right direction. That hasn't happened. Part of it was a funding issue also - those packages are very, very expensive - so we just didn't go there.

However, at present a project is being implemented on the internal website which takes a similar direction, enabling government employees to put information on the website about active projects - their status, who is involved, who the contact people are, and what the timeline is.

Another knowledge sharing instrument employed is that of manuals, or standard operational procedures, such as in DGP 2, where the team was initially hired for a fixed period of 2.5 years, currently exploring ways to let the knowledge accumulated in the team flow back into the government:

Our goal is to [document] the entire output that is related to IT systems, be it the intranet, the partial projects, or the portal; [...] to have created manuals which don't leave any questions unanswered regarding how they originated, who bears which responsibilities, and who administrates it. So, it is our goal to take this operational knowledge back into the government. 
Imitation. As asserted before, digital government is a governance mode that challenges the traditional functioning of government in many ways. This is particularly evident with regard to "looking over the fence", or monitoring and copying the practices of other agencies and governments. Of course agencies have compared themselves to other agencies before, but the Internet offers a whole new range of possibilities for replications the work of others - at least to a certain extent - because of the very nature of the World Wide Web. Replication from other agencies involves knowledge transfer rather than sharing, and is often regarded as an effective effort to avoid "reinventing the wheel", as has been repeatedly stated by members of all projects. A member of DGP 3 gives an example:

I would say a lot of [my work] is plagiarizing and relying on other people's, other agencies' websites, sometimes doing a lot of hard work and wading through their online or print publications, pulling out what it is the business needs, and presenting it in a user-friendly way.

Imitation is mostly encouraged by the "imitated" agencies, especially if given credit for, since it promotes the image of the duplicated website:

We certainly do communicate with agencies by email, just letting them know what our efforts are. We go out on the speaking circuit and speak to [...] explain what the portal is all about [...]. You know, we do agency presentations.

DGPs often serve as a hub for diffusing best practices among the agencies, as stated members of all projects. For example, a member of DGP 3 said:

We had to look for best practices, and then share those best practices across the enterprise. It doesn't make sense for one agency to have developed an expertise and not share that expertise across several different agencies that might have similar missions.

Learning. Levels of learning activities were surprisingly high both within and across

DGPs. Learning occurs through a variety of processes at the individual and organizational level. Three major processes emerged with regard to DGPs, presented in the order of rising task complexity: (1) Trial and error, (2) Exchange with other agencies, and (3) Collaboration.

The first process, trial and error, refers to "learning by doing". As the project manager of DGP 4 affirmed:

The key to what we do is, we try to take a very practical approach and to learn by doing. And the only way you really find out what the issues are is to go get into it.

A member of DGP 2 recounts that much was learned during the process on a step-by-step basis, the situation encountered at the beginning being different from what had been expected (in 
terms of prerequisites). Only over time it became clear what was missing, and what else could be useful. This process might sound trivial at first, but considering the fear of failure that often characterizes government employees, it actually is remarkable. The communications director of DGP 2 accounted for fear of failure in the following way:

The fear [of government employees] of doing something in a way less than perfect primarily exists toward the outside world. Generally, the way it works in government is that when government makes a mistake, you can read about it in the papers the following day. This, in my view, is the predominant fear of government employees.

Managers had to fight this fear at all levels, in one case carefully trying to establish a culture of 'courage to compromise', because 'there are no perfect decisions' (DGP 4).

The second process that emerged is the exchange with other agencies. As I put forward earlier, the Internet facilitates duplication of what are considered best practices. However, mere replication is not sufficient for successful implementation, no matter how successful the original practice might be. What makes it successful is the exchange with other agencies. In this context, exchange is similar to collaboration, but different in that it is less concrete than collaboration. A member of DGP 4 gives an example:

[Other states] call us up about a particular issue or we'll call them up: "How did you do this?" "What was the focus?" "What vendor did you work with?" "What did you learn in the process that we might benefit from?" "What's your best practice in this area? We're getting started in a new area." We do that all the time.

Collaboration, the third process of learning, can be viewed as... "A confederation of all the organizations working together, with a common enterprise perspective” (DGP 4). In DGP 4, learning through collaboration has been institutionalized in the DG "academy":

What we do is, we started off with the template approach, where we bring a bunch of agencies together that care a common technical service like printing, or licensing, or that kind of thing. And we'll bring them together, that's kind of a community of interest, agencies that have a similar business process, and we'll decide to build a new class of services like a licensing application, a new class of online services like online licensing or online permitting, or some of those things.

At a less sophisticated level, members of DGP 2 and DGP 3 recounted mutual learning through collaboration, as told by a channel manager of DGP 3:

I think all of us rely on feedback and assistance from a great number of people, in determining what makes the most sense to put out there on our channels. And in particular, with the municipal channel we've really tried to involve the cities and towns, because one thing that I've learned in 25 years in public government, nothing annoys them more than being told, "I'm from the state, and this is what you need." 
Meetings. Meetings of involved parties proved to be the most effective way to share knowledge in all projects during the conceptual phase. A plausible reason for this might be the generally assessed preference by government officials for face-to-face contact. It is through the meetings of task forces, work groups, and steering committees that the project ideas were generated, refined, and brought towards implementation. In DGP 2, the deputy director organized an "e-project-lunch", a monthly networking event where managers of partial projects would listen to a speaker on some relevant topic and subsequently have the occasion to share experiences, views, and questions with peers.

The meeting frequency of important parties in the conceptual phase (task forces, work groups, and steering committees) decreased significantly when projects entered the implementation phase, as told by a channel manager of DGP 3, who is now meeting with small, focused groups of stakeholders:

Until very recently we were meeting a lot face to face. You know, once this area was launched, they stopped the frequent meetings, and now what I'm doing instead is tending to meet with people one-on-one or small groups, to focus on a particular area, as opposed to the broad realm of the municipal channel.

In DGP 2, the meetings of the steering committee have been temporarily suspended because they were deemed unnecessary at the present stage:

We haven't had any steering committee meetings in a while, for the simple reason that people didn't feel responsible anymore, and also because they didn't invest the time necessary to prepare for the meetings. In addition, when the steering committee was originally formed, the idea behind it was to have a contact person in each department, who would carry the project out to his department. This task is now mainly done by the managers of partial projects, and by those folks who are in charge of harmonizing the websites.

\section{Coordination mechanisms of knowledge}

Three coordination mechanisms for knowledge sharing were found to exist concurrently in the four cases; hierarchy, social networks, and group dynamics. As would be intuitive to assume, hierarchical reporting structures, and especially power and authority, had a strong influence on knowledge sharing in DGPs. However, the effects of social network relationships emerged as being extremely powerful, oftentimes overruling the given hierarchical structures. As could be expected, group dynamics had a lesser effect on cross-agency knowledge sharing, but they significantly shaped the advancement of DGP processes. 
Hierarchy. As discussed above, whereas the traditional understanding of hierarchies is that decisions are made top-down and reporting is made bottom-up, DGPs require collaborative structures of decision-making, both within and across agencies. This tension between existing and required communication structures was a predominant topic for all DGPs in this study. For example, the web master of DGP 3 explained the difficulties of communicating bottom-up with respect to suggestions for improvement:

A lot of it is because we're working with people who have a job, they have a boss, their boss ultimately is the commissioner of their agency, whose concerns are their goals and objectives, mandates from the legislature or from the governor's office, and for the webmaster down here at the bottom of the pile to say, "Hey, we should do this", just either never makes it to the top, or is just not a priority at the top.

On the other hand, individuals across cases stated the importance of referring to rules as a tool for reinforcing the adherence of agencies to the project, therefore availing themselves of the hierarchical power structure:

There are agencies that said, "Look, gee, we've invested in our own marketing, we don't want to confuse it with yours." In those cases we had to be a little more strong in our communication and our sales pitch and say, "look, we've already decided at the highest level of government, this is an enterprise-wide initiative, you need to put aside your desire to market your own agency and join the team."

In even stronger terms, a member of DGP2 claimed that turning rules into regulations was "the only possibility to achieve something in government", which is why they elaborated a link policy that subsequently was submitted to parliament for ratification, thus obliging all agencies to adopt the policy. This claim was only partially confirmed by a member of DGP 3, who stated that agencies can be "convinced" to participate in cross-agency collaborations, for example by leveraging budget pressure:

So when there's no money and you say, "You can't afford to do that, unless you use the shared service that we're putting in, and if you follow our rules", well then they follow the rules so they can get the money, but not because - because the basic nature of things is still they get an edict from the governor or from the legislature, and that establishes the priority for that agency, and those edicts have nothing to do with cooperating with other agencies.

Overall, the most effective mechanism for convincing agencies to participate and therefore to make a DGP successful was executive sponsorship (a term used in DGP 4), or "direction and commitment from the very top levels of government", as one senior member of

\section{DGP 3 stated:}

The problem that we find is that government is still organized the way government is organized, it's very hierarchical, so that if you don't get buy-in at the top level, where the agency heads are talking to each other and say, "yes, our teams are going to work together and are going to share this application", it's not going to happen. It's just not going to happen. [But] when you have the governor or you have the [secretary of a department] at a cabinet meeting talk about, "this secretary and this secretary need to work together to 
create this DG application", that's as important as the worker bee level is, because that gives the legitimacy to those worker bee people to work with each other.

In DGP 4, the project manager stated that “...executive sponsorship brings priorities and it brings resources”. The governor holds agency directors accountable in a performance contract, creating a commitment on the part of the agencies to put a certain number of services online.

A major challenge for all projects proved to be the overcoming of existing 'stovepipes', or the inability to communicate across functional divisions and organizational boundaries. With the objective in mind to present a one-stop government to the citizens, the DGPs found themselves in a position where they attempted to bridge the gaps that exist between current online transactions, which mainly followed the traditional agency-by-agency approach. An individual from strategic planning in DGP 3 explained this challenge by saying:

I think that one of the challenges with DG from the very beginning [...] is that there are no mechanisms, there are no organizational structures that foster cross-agency collaboration and integration. Budgets are agency-specific, line-item specific ${ }^{\text {iii }}$, and statutes and regulations are agency-specific. There are statutes and regulations that actually prohibit data sharing across agencies, probably for a lot of good reasons but sometimes for not-very-good reasons, just because of territoriality. [...] So that's the constant struggle, just how to get that horizontal view when everything is pointing to a very vertical view.

The communications officer in DGP 2 put personal effort into bridging the boundaries between agencies by creating "internal information structures”, convincing the government that each department appoint an information delegate, and arranging regular meetings with them. However, individuals in all four projects stated that the integration of agencies across government runs against the interest of many agencies, who "actively try to keep their own system running and fend everything that might challenge their hierarchy and their right to exist”, as expressed by one member of DGP 2. This "entrenched interest in keeping the bureaucracy the way it is" was one of the reasons in DGP 3 to centrally coordinate the DGP:

[...] Because the agencies were part of the problem - they were all providing their own narrow little piece of information, and it wasn't being tied together. [...] In order to achieve the goal of an intentions-based website, one face of government, it's not going to be done in a decentralized fashion. Basically, [the portal] is one big centralization effort, even though we like to talk about decentralized content management.

The approach of “centralized decentralization” of DG initiatives, as it is called in DGP 1, denoting that initiatives are generated in a decentralized fashion (i.e. in the agencies), but coordinated centrally, is (or was) generally followed by all four projects. In the case of DGP 4, the most advanced project, the central coordination was relaxed somewhat, delegating the responsibility for the applications to the agencies themselves. Each agency is now responsible 
for the development and deployment of online services, having the legislative authority to deliver those services and collect the necessary data.

Social networks. As anticipated earlier, social network relationships emerged as being extremely powerful, oftentimes overruling the given hierarchical structures. In all four projects, individuals relied on informal networks within and across agencies on a daily basis. As an individual explained to me in DGP 3, retrieving information through informal channels is considered normal practice in government:

The first thing you do when you're looking for something is get on the phone and start calling around. [...] It's just a matter of, once you got the right person, to get them to give you this information you're looking for. From that perspective, having built personal rapport really goes a long way, if they know you they're more likely to help you, [...] if you have personal relationships established, you're more likely to get results....

From a process view, DGPs can be divided into two major phases; conception and implementation of a project. These phases are reflected in the social networks of the projects. Before attempting to justify this claim, it is useful to recall that the four projects find themselves in different stages of implementation; DGP 1 currently being in a conceptual phase, DGP 2 and DGP 3 having recently entered the implementation phase, and DGP 4, having implemented a large part of the applications envisioned in the strategic plan. Many social networks came into existence during the conceptual phase of the projects, where people from different agencies and interest groups came together to jointly consider DG. For example, a channel manager from DGP 3 stated:

From that whole process of those access channel workgroups, I got to know more people, and became more familiar with their content, information on their sites and things like that. So now that the workgroup period is completed, [...] I talk to and follow up with people, and kind of check in with them, take requests, follow up on requests.

The project director of DGP 2, who was hired from the private sector to manage the project, stated that he socialized with representatives from the agencies through the (centrally coordinated) conception of their partial projects. The deputy director of DGP 2 explained how the launch of the Intranet was conceived as a way of casting a net of contacts across agencies, encouraging people to share their needs and give their input. As recounted above, she also explicitly promoted the creation of networks by introducing a monthly networking event for managers of partial projects. Similar stories can be told about the other projects, with the common denominator that most of the individuals involved were surprised by how conceptual 
meetings brought together so many like-minded people for the first time. Fundamentally then, there were weak ties as well as large, sparse networks in the conceptual phase.

These stories pushed me to study the informal networks more rigorously as I was writing up the results of my fieldwork. The resulting network diagrams are shown in figures 2 and 3 . In figure 2, the four networks are displayed in a circular fashion to better visualize the density of ties, and in figure 3 the networks are rearranged in order to visualize the functional subdivisions. When looking at figure 2, it is apparent that the density of ties increases gradually from DGP 1 to DGP 4, indicating weak ties (in terms of frequency of communication) in the projects that are in their conceptual phase. Due to the varying stages of advancement of the four projects, this phase can be observed directly only in the network of DGP 1, whereas in the other cases I had to rely on the accounts of previous configurations by the people who are currently involved in the project.

In the implementation phase, the knowledge networks of DGPs gain in density, indicating stronger ties. Team members have established most of their contacts and use them for "getting the work done”. Contrarily to the conceptual phase, this development can be recognized in DGP 2 and DGP 3, but becomes clearly visible in DGP 4, the most advanced project.

Figure 2: Density of ties in knowledge networks

A different way of looking at the knowledge networks of DGPs is by their functional subdivision. This representation allows a mapping of the informal network on the formal bureaucratic structure by rearranging the actors according to their affiliation and their position in the hierarchy, without altering the informal ties between individuals. Accordingly, figure 3 shows the same networks as figure 2, but the functional subdivision highlights the ties across agencies, as well as horizontal and vertical communication links. In this representation the increasing density of ties is also visible, but in addition it becomes evident that the configuration of the networks changes considerably from DGP 1 to DGP 4 . In the case of DGP 1, the network is remarkably sparse (actors with few ties from many different agencies), whereas in DGP 2 and DGP 3, the networks evolve around the project teams, which are tightly-knit and fairly integrated into the larger project group. DGP 4, at the other end of the scale, features multiple tightly-knit 
groups embedded in a dense network. Among many possible interpretations, it appears particularly interesting to observe that (1) DGP 4, the project in the most advanced stage, is very strongly integrated across functions; (2) DGP 2 has virtually no ties to IT; (3) in all projects the individual in charge of communications plays an important role; (4) the individual who was the initial driving force of the project is generally better connected than the actual project manager; and (5) in all cases there is a discrepancy between hierarchical functions and positions in the social network of individuals.

Figure 3: Functional subdivision of knowledge networks

Group dynamics. As stated above, the framework of group dynamics is one that views people as coexisting in groups because of functional, cognitive, and structural interdependencies that link them together. Due to the configuration of the projects in this study, only DGP 2 and DGP 3 were well suited for observing group dynamics, being the only two projects with a closely-knit team. Whereas in DGP 1 the group was very loosely connected, in DGP 1 multiple groups evolved as a consequence of early DG initiatives, serving as "knowledge hubs" in the larger network. It would have been extremely interesting to study the interdependencies of these groups in detail, but the necessary resources in terms of manpower and time were beyond the possibilities at my disposal for this study.

Thus, considering DGP 2 and DGP 3, there are some similarities other than the configuration of the DGP as a team: in both cases, the project managers were hired from 'the outside, iv , and subsequently had the opportunity to hire the team members according to their own judgment, with a few exceptions. The project manager of DGP 3 described his preferences regarding the composition of his team in the following way:

Now, I'm not looking for anybody that is all about work. I want people to have outside interests. I certainly have outside interests. [...] I've had people who have worked for me who were like that, and you certainly get great short-term benefits out of them, but in the long run it can be more destructive than at the beginning. So I encourage people to not live work, that we have a lot to do, and I want them to be focused while they're here, but we laugh, we celebrate victories, we console each other with defeats, we try to stay together as a team.

Hence it is not surprising that the group dynamics of these two teams are extremely positive. In terms of shared mental models, these seem to be a nearly perfect match in DGP 2, 
since it is a homogeneous group where knowledge, skills, attitudes, preferences, tendencies are similar. Team-specific knowledge of teammates helps members to better tailor their behavior to what they expect from teammates. This internal strength apparently facilitates the interaction with externals, such as IT people or managers of partial projects:

Because of the partial projects that we coordinate, many people from the state government come to us, and I think that they like the fact that they are coming to a young and dynamic team. [...] I think they really appreciate that. [...] The intranet project was a very positive experience, that we were able to transmit our own dynamics from the project to people, especially the IT community - actually people even congratulated us on the project in the end; people who had made no secret of their skepticism in the beginning, who had even reacted rather agressively.

Overall, it is apparent that projects members of all four DGPs are functionally interdependent, since they share a common task that cannot be reached by an individual alone. As for cognitive interdependence, I have shown throughout this study that informal social communication plays a crucial role in all four projects. However, a collective sentiment in the Durkheimian way was recounted only by DGP 4. F inally, all DGPs showed a high structural interdependence, reinforcing Brass's (1984) claim that informal structures shadow formal structures.

\section{Exploration and exploitation: Toward a theory of knowledge sharing in DGPs}

In the previous section, I have analyzed the modes of knowledge sharing and the coordination mechanisms of knowledge in four DGPs. I have shown how these projects differ in their stage of advancement, in the functional subdivisions of their actors, and in their organizational form; and how these factors affect the way knowledge is shared in the projects. In this section, I reassemble the salient features of DGP processes that emerged during the analysis and distill them into core categories . Two main dimensions in terms of tasks emerged in achieving the project objectives, each of them subdivided into two phases: (1) Conception and implementation, and (2) Exploration and exploitation. I present the developed theory by means of four propositions, and conclude the chapter with a discussion of the theory.

\section{Task dimension I: Conception and implementation}

Throughout this study, I have asserted that DGPs may be subdivided into two major phases; conception and implementation. At first glance, this finding appears to be trivial, as the very nature of any project requires that the project be conceived first, and implemented subsequently. What makes this pronouncement relevant is the fact that these two phases necessitate certain characteristics of tasks. 
Borrowing the concept of decomposability from Herbert Simon (1981), I propose that the conception and implementation phases move along a continuum of task decomposability. Simon illustrates this concept with a parable of two watchmakers (Simon, 1981:200):

There once were two watchmakers, named Hora and Tempus, who manufactured very fine watches. Both of them were highly regarded, and the phones in their workshops rang frequently - new customers were constantly calling them. However, Hora prospered, while Tempus became poorer and poorer and finally lost his shop. What was the reason?

The watches the men made consisted of about 1,000 parts each. Tempus had so constructed his that if he had one part assembled and had to put it down - to answer the phone, say - it immediately fell to pieces and had to be reassembled from the elements. The better the customers liked the watches, the more they phoned him and the more difficult it became for him to find enough uninterrupted time to finish a watch.

The watches that Hora made were no less complex than those of Tempus. But he had designed them so that he could put together subassemblies of about ten elements each. Ten of these subassemblies, again, could be put together in a larger subassembly; and a system of the latter subassemblies constituted the whole watch. Hence, when Hora had to put down a partly assembled watch to answer the phone, he only lost a small part of his work, and he assembled his watches in only a fraction of the man-hours it took Tempus.

Hence, the concept of decomposability represents the extent to which large tasks can be decomposed into smaller, specialized tasks. With regard to the two phases of DGPs, the degree of decomposability is low during the conception phase, requiring the collaboration of different agencies and stakeholders; and it is high in the implementation phase, once the necessary tasks have been defined.

Proposition 1. The conception and implementation phases of DGPs move along a continuum of task decomposability, where the decomposability is low during conception and high during implementation.

\section{Task dimension II: Exploration and exploitation}

The second dimension emerged in the course of my analysis of knowledge sharing activities. It describes the variation in the content of knowledge sharing activities, moving from discovery to retrieval of knowledge. In other words, the first phase is dedicated to the exploration of knowledge, while the second phase involves the exploitation of knowledge. This dichotomy was originally coined by Schumpeter as exploration of new possibilities and exploitation of old certainties (Schumpeter, 1934), and presented to the organizational learning community by James March in a famous Organization Science article (March, 1991). According to March, 
Exploration includes things captured by terms such as search, variation, risk taking, experimentation, play, flexibility, discovery, innovation. Exploitation includes such things as refinement, choice, production, efficiency, selection, implementation, execution.

Returning to the second task dimension, the two phases demand certain types of organization: while there is greater reliance on networks during the exploration phase, a hierarchical structure is more efficient in the exploitation phase. From a governance perspective, this is equivalent to asserting that collaboration among actors in a network prevails during the exploration phase, and the coordination and control of actors is more important during the exploitation phase.

In an analogy to the first dimension, I propose that exploration and exploitation also move along a continuum, in this case given by the configuration of ties in the informal network. The network is sparse in the exploration phase and dense in the exploitation phase, corresponding to weak ties during exploration and strong ties during exploitation.

Proposition 2. The exploration and exploitation phases of knowledge move along a continuum of network configuration, where the network is sparse during exploration and dense during exploitation.

Assembling the parts: A theory of knowledge sharing in DGPs

It is intuitive to assume that the two task dimensions occur concurrently, and that they influence each other in some way. Before I draw a conclusion on this assertion, a few remarks need to be made regarding the characteristics of the proposed dimensions. The first task dimension, conception and implementation, builds on subsequent phases, therefore carrying a temporal connotation. Similarly, the phases of the second task dimension, exploration and exploitation, might succeed each other temporally, but their main characteristic is that they are content-related. As March (1991) affirmed, a combination of exploration and exploitation must be present at all times. Therefore, it can be asserted that the two task dimensions are interrelated. The implementation of DG requires a balanced mix of exploration and exploitation, where exploration is more important in the conceptual phase, and exploitation becomes more fruitful in the implementation phase. 
Proposition 3. In DGPs, task dimension I (conception and implementation) and task dimension II (exploration and exploitation) are interrelated, where exploration is primarily associated with the conceptual phase, and exploitation is mainly linked to the implementation phase.

Since the two task dimensions discussed above are interrelated, it makes sense to arrange them in a two-by-two matrix. The figure below depicts the matrix, summarizing the theory developed in this chapter. Each quadrant resulting from the interrelation between the two task dimensions is filled with concepts that were drawn from the findings presented in chapter four. The twelve concepts (out of the original 160), which retained their significance after repeated coding procedures, address the decision-making processes of DGPs (vision, roadmap, steering committee, and stakeholders’ inputs; see Scharf, 2003), the coordination mechanisms of knowledge (collaboration, integration and aggregation, and coordination and control), and the modes of knowledge sharing (exchange with other agencies, trial and error, group meetings, imitation, and documents and databases).

Figure 4: Exploration and exploitation of knowledge in DGPs

Within the quadrants, the concepts are positioned according to their loose or structured connotations. Stakeholders' inputs in the conceptual phase come in an unstructured form (loose conception) from a sparse network (loose exploration). A project's vision is broad, but its exploration is structured through a strategy. The steering committee supervises the conceptual phase, giving a general direction to follow. Exchange with other agencies in the conceptual phase is structured by functions and tasks, but the search for knowledge can be broad. The roadmap represents the structure for the conceptual phase, giving clear directions on how to proceed. Trial and error in the implementation phase is an unstructured search strategy for improvement. Integration and aggregation can occur in all forms of exploration during the implementation phase. Group meetings during implementation are structured events with a structured agenda to explore new ideas. Imitation occurs in the implementation phase and utilizes the knowledge of others. Finally, documents and databases serve the purpose of a structured implementation and are instruments for a structured exploitation of knowledge. 
With regard to the types of organization, I have shown that DGPs rely on sparse networks during the conceptual phase of the project, and tend to employ teams or tightly-bounded groups when the project moves towards implementation.

Proposition 4. In a lifecycle view of a DGP, the project's advancement is driven by effective knowledge sharing, moving from exploration in a sparse network during the conceptual phase to exploitation in one or more dense groups in the implementation phase.

\section{Discussion}

The presented theory shows that the implementation of DG requires a balanced mix of exploration and exploitation, where exploration is more important in the conceptual phase, and exploitation becomes more fruitful in the implementation phase. From a governance perspective, collaboration among actors in a network prevails during the exploration phase; and the coordination and control of actors is more important during the exploitation phase. With regard to the types of organization, I have shown that DGPs rely on sparse networks during the conceptual phase of the project, and tend to employ teams or tightly-bound groups when the project moves towards implementation.

Some caveats to this theory can be described by means of the matrix representation. Two of the quadrants, conception/exploitation to the upper right and implementation/exploration to the lower left are less immediate than the other two, as they appear as 'side products' of the general flow of the model. With the present results it is also difficult to demonstrate that apart from the general flow there exists a feedback loop, leading from the exploitation of knowledge in one partial project to the exploration of new possibilities. This feedback loop would need to be studied in a longitudinal analysis. Furthermore, not every cell within the quadrants could be filled with meaning. It might be that this is empirically impossible, but such an assertion certainly requires additional research into the model. 


\section{Conclusions}

In this study I have shown that knowledge sharing plays a crucial role in DGPs. These projects bring together individuals from different organizational units, with different skill sets, and different mental models, to work on a common goal - the implementation of the project. Of particular importance in this context are the modes and influencing factors of knowledge sharing, and the coordination mechanisms of knowledge. Knowledge sharing processes are a central feature of the functioning of government, but, with very few exceptions (cf. Blau, 1963), they have received surprisingly little attention in the literature. The importance of knowledge sharing has become even more evident with the rise of digital government (DG) initiatives, as these have a networking effect on bureaucracies. The fact that individuals with differing skill sets and from different organizational units work on a common task creates a network that coexists with the functional subdivision of tasks within the organization. Common tasks by their nature require knowledge sharing in order to be fulfilled successfully. With multiple agencies and multidisciplinary knowledge coming together, it is necessary to combine and reconnect the required knowledge. The study combined a qualitative exploratory case study design and a grounded theory approach, with the aim of theory building through the comparative analysis of case studies. The sample for this study consisted of four DGPs in two different countries, Switzerland and the United States. Findings of the empirical study shed light on the modes of knowledge sharing and the coordination mechanisms of knowledge in the four DGPs. I showed how these projects differ in their stage of advancement, in the functional subdivisions of their actors, and in their organizational form; and how these factors affect the way knowledge is shared in the projects. The study's main contribution is a theoretical model for knowledge sharing in DGPs. It ties together processes and content of knowledge sharing through two task dimensions, each of them subdivided into two phases: (1) Conception and implementation of the project, and (2) Exploration and exploitation of knowledge. I showed that the implementation of DG requires a balanced mix of exploration and exploitation of knowledge, where exploration is more important in the conceptual phase, and exploitation becomes more fruitful in the implementation phase. I found that different configurations of knowledge networks in DGPs are related to different stages in the advancement of the project: DGPs rely on sparse networks during the conceptual phase of the project, and tend to employ teams or tightly-bound groups when the project moves towards implementation. 


\section{Research implications}

The study endeavors to break new ground by analyzing government agencies through an organizational behavior lens. It contributes to the existing body of theory on knowledge sharing and organizational learning by applying these theories to modern government agencies, and thus attempting to bridge a gap that has been left since Peter Blau's “The Dynamics of Bureaucracy” (1963). It also contributes to the public management literature by shedding light on the human processes that drive interagency collaboration. The study contributes to social psychology by positioning project teams in the context of their organizations. It adds to organizational theory by building on the ongoing discourse of how organizational forms affect performance.

\section{Policy implications}

The presented model of knowledge sharing in DGPs assists public managers in understanding how to conceive and implement a DGP more effectively by emphasizing the crucial importance of knowledge sharing in inter-agency collaboration. Along the core categories of the model, exploration and exploitation, some specific practical recommendations for the conception and implementation are the following:

Exploration. In the conceptual stage, it is important to draw on groups of all possible stakeholders, bringing them together in task forces, focus groups, or work groups. At this stage, possibilities are being explored, and it is preferrable to choose from a vast array of possibilities rather than having narrowed down the alternatives from the outset. Stakeholder groups include, in random order, representatives from all levels of government, private sector representatives, vendors, non-profit organizations, interest groups, activists, citizens, small businesses, and professional organizations. If a consultant is hired, it is crucial that the client agency take the project leadership, collaborating closely with the consultant in every stage of the contract. Even if the conception of a project is already well on its way, employing focus groups can be a good way of assessing whether the direction the project is taking is in line with its stakeholders' expectations. It pays to nurture the creation and maintenance of informal networks during these events. A big part of organizational learning happens at meetings and in exchanges with other agencies. Ownership of ideas is a major motivational factor, and executive sponsorship is a must. 
Exploitation. The implementation of a DGP requires some structured process. At an early stage, this could be done by a team of individuals working exclusively on the project, or a single individual who is clearly in charge of coordination efforts. Whereas large cross-agency projects such as the IT infrastructure should be managed centrally, ownership of projects should be given to the agencies where the idea for the project originated, but duplications avoided through central coordination. To efficiently serve as a knowledge hub, DGP teams should actively facilitate the exchange among agencies by giving incentives such as shared services, and by helping them partner up with like-minded individuals and agencies. 


\section{References}

Adler, P. S., \& Borys, B. (1996). Two types of bureaucracy: Enabling and coercive. Administrative Science Quarterly, 41(1), 61-89.

Agranoff, R., \& McGuire, M. (1999). Expanding intergovernmental management's hidden dimensions. American Review of Public Administration, 29(4), 352-369.

Agranoff, R., \& McGuire, M. (2001). Big questions in public network management research. Journal of Public Administration Research and Theory, 11(3), 295-326.

Alderfer, C. (1977). Group and intergroup relations. In J. R. Hackman \& J. Suttle (Eds.), Improving the Quality of Work Life (pp. 227-296). Pacific Palisades, CA: Goodyear.

Argote, L., Ingram, P., Levine, J. M., \& Moreland, R. L. (2000). Knowledge transfer in organizations: Learning from the experience of others. Organizational Behavior and Human Decision Processes, 82(1), 1-8.

Argyris, C., \& Schön, D. (1978). Organizational Learning: A Theory of Action Perspective. Reading, MA: AddisonWesley.

Arrow, K. J. (1974). Limits of Organization. New York: Norton \& Company, Inc.

Bardach, E. (1999). Getting Agencies to Work Together: The Practice and Theory of Managerial Craftsmanship. Washington, DC: Brookings.

Barley, S. R. (1990). The alignment of technology and structure through roles and networks. Administrative Science Quarterly, 35(1), 61-103.

Barzelay, M. (1992). Breaking Through Bureaucracy: A New Vision For Managing in Government. Berkeley, Los Angeles, Oxford: University of California Press.

Barzelay, M. (2001). The New Public Management: Improving Research and Policy Dialogue. Berkeley, CA: University of California Press.

Bavelas, A. (1950). Communication Patterns in Task-Oriented Groups. Journal of the Acoustical Society of America, 22(6), 723-730.

Bell, D. (1973). The Coming of the Post-Industrial Society: A Venture in Social Forecasting. New York: Basic Books.

Bellamy, C., \& Taylor, J. (1998). Governing in the Information Age. Buckingham: Open University Press.

Blau, P. M. (1963). The Dynamics of Bureaucracy (2nd, rev. ed.). Chicago: University of Chicago Press.

Blau, P. M., \& Schönherr, R. A. (1971). The Structure of Organizations. New York, London: Basic Books.

Bouty, I. (2000). Interpersonal and interaction influences on informal resource exchanges between R\&D researchers across organizational boundaries. Academy of Management Journal, 43(1), 50-65.

Brass, D. J. (1984). Being in the right place - a structural analysis of individual influence in an organization. Administrative Science Quarterly, 29(4), 518-539.

Brown, J. S., \& Duguid, P. (2001). Knowledge and organization: A social-practice perspective. Organization Science, 12(2), 198-213.

Cannon-Bowers, J. A., Salas, E., \& Converse, S. A. (1993). Shared mental models in expert team decision making. In N. J. Castellan (Ed.), Current Issues in Individual and Group Decision Making. Hillsdale, NJ: Erlbaum.

Cartwright, D., \& Harary, F. (1956). Structural balance - a generalization of Heider theory. Psychological Review, 63(5), 277-293.

Charmaz, K. (2000). Grounded theory - objectivist and constructivist methods. In N. K. Denzin \& Y. S. Lincoln (Eds.), Handbook of Qualitative Research (2nd ed.). Thousand Oaks, CA: Sage.

Cohen, M. D., \& Bacdayan, P. (1994). Organizational Routines Are Stored as Procedural Memory - Evidence from a Laboratory Study. Organization Science, 5(4), 554-568. 
Contractor, N., Carley, K., Levitt, R., Monge, P. R., Wasserman, S., Bar, F., et al. (2000). Co-evolution of knowledge networks and 21st century organizational forms: Computational modelling and empirical testing (Working Paper No. TEC2000-01). Urbana-Champaign, IL: University of Illinois.

Cox, T. H., Lobel, S. A., \& McLeod, P. L. (1991). Effects of ethnic group cultural differences on cooperative and competitive behavior on a group task. Academy of Management Journal, 34(4), 827-847.

Crotty, M. (1998). The Foundations of Social Research. London: Sage.

Crozier, M. (1964). The Bureaucratic Phenomenon. Chicago, IL: University of Chicago Press.

Cummings, J. L. (2002). Knowledge Transfer Across R\&D Units: An Empirical Investigation of the Factors Affecting Successful Knowledge Transfer Across Intra- and Inter-Organizational Units. Unpublished Dissertation, George Washington University, Washington, DC.

Cyert, R. M., \& March, J. G. (1963). A Behavioral Theory of the Firm. Englewood Cliffs, NJ: Prentice-Hall.

Czarniawska, B. (1997). Narrating the Organization: Dramas of Institutional Identity. Chicago, IL: University of Chicago Press.

Dalton, M. (1959). Men Who Manage: Fusions of Feeling and Theory in Administration. New York: John Wiley.

Dirks, K. T., \& Ferrin, D. L. (2001). The role of trust in organizational settings. Organization Science, 12(4), 450467.

Drucker, P. (1993). Post-Capitalist Society. New York: Harper Business.

Dyer, J. H., \& Nobeoka, K. (2000). Creating and managing a high-performance knowledge-sharing network: The Toyota case. Strategic Management Journal, 21(3), 345-367.

Earley, P. C. (1994). Self or group - cultural effects of training on self-efficacy and performance. Administrative Science Quarterly, 39(1), 89-117.

Economist. (2000, 24 June). Survey Government and the Internet. The Economist.

Edmondson, A. (1999). Psychological safety and learning behavior in work teams. Administrative Science Quarterly, 44(2), 350-383.

Eisenhardt, K. (1989). Building theories from case study research. Academy of Management Review, 14(2), 532-550.

Ely, R. J., \& Thomas, D. A. (2001). Cultural diversity at work: The effects of diversity perspectives on work group processes and outcomes. Administrative Science Quarterly, 46(2), 229-273.

Erez, M., \& Somech, A. (1996). Is group productivity loss the rule or the exception? Effects of culture and groupbased motivation. Academy of Management Journal, 39(6), 1513-1537.

Farace, R. V., Monge, P. R., \& Russell, H. M. (1977). Communicating and Organizing. Reading, MA: AddisonWesley.

Forsyth, D. R. (1983). Group Dynamics (2nd ed.). Pacific Grove, CA: Brooks/Cole Publishing Company.

Fountain, J. E. (1999). The Virtual State: Toward a Theory of Federal Bureaucracy in the 21st Century. In E. C. Kamarck \& J. S. Nye, Jr. (Eds.), Democracy.com? Governance in a Networked World. Hollis, NH: Hollis.

Fountain, J. E. (2001). Building The Virtual State: Information Technology and Institutional Change. Washington, D.C.: Brookings.

Galbraith, J. (1973). Designing Complex Organizations. Reading, MA: Addison-Wesley.

Gibson, C. B. (1999). Do they do what they believe they can? Group efficacy and group effectiveness across tasks and cultures. Academy of Management Journal, 42(2), 138-152.

Gittell, J. H. (2002). Coordinating mechanisms in care provider groups: Relational coordination as a mediator and input uncertainty as a moderator of performance effects. Management Science, 48(11), 1408-1426.

Glaser, B. G., \& Strauss, A. L. (1967). The Discovery of Grounded Theory: Strategies for Qualitative Research. New York: Aldine Publishing. 
Goetz, J. P., \& LeCompte, M. D. (1984). Ethnography and Qualitative Design in Educational Research. Orlando, FL: Academic Press.

Goodman, P. S., Griffith, T. L., \& Fenner, D. B. (1990). Understanding technology and the individual in an organizational context. In P. S. Goodman \& L. Sproull (Eds.), Technology and Organizations (pp. 1-33). San Francisco: Jossey-Bass.

Granovetter, M. S. (1973). Strength of weak ties. American Journal of Sociology, 78(6), 1360-1380.

Grant, R. M. (1996). Toward a knowledge-based theory of the firm. Strategic Management Journal, 17(Winter), 109-122.

Grant, R. M., \& Baden-Fuller, C. (1995). A knowledge-based theory of inter-firm collaboration. Academy of Management Journal, Best Paper Proceedings, 17-21.

Gupta, P. P., Dirsmith, M. W., \& Fogarty, T. J. (1994). Coordination and control in a government agency contingency and institutional theory perspectives on GAO audits. Administrative Science Quarterly, 39(2), 264-284.

Guzzo, R. A., \& Dickson, M. W. (1996). Teams in organizations: Recent research on performance and effectiveness. Annual Review of Psychology, 47, 307-338.

Habermas, J. (1971). Knowledge and Human Interests. Boston, MA: Beacon Press.

Habermas, J. (1979). Communication and the Evolution of Society. Boston, MA: Beacon Press.

Hackman, J. R. (1987). The design of work teams. In J. Lorsch (Ed.), Handbook of Organizational Behavior (pp. 315-343). Englewood Cliffs, NJ: Prentice-Hall.

Hansen, M. T. (1999). The search-transfer problem: The role of weak ties in sharing knowledge across organization subunits. Administrative Science Quarterly, 44(1), 82-111.

Hansen, M. T. (2002). Knowledge networks: Explaining effective knowledge sharing in multiunit companies. Organization Science, 13(3), 232-248.

Hickson, D. J., Hinings, C. R., Lee, C. A., Schneck, R. E., \& Pennings, J. M. (1971). Strategic contingencies theory of intraorganizational power. Administrative Science Quarterly, 16(2), 216-229.

Homans, G. (1950). The Human Group. New York: Harcourt, Brace.

Hoopes, D. G., \& Postrel, S. (1999). Shared knowledge, 'glitches', and product development performance. Strategic Management Journal, 20(9), 837-865.

Jackson, S. E. (1996). The consequences of diversity in multidisciplinary work teams. In M. West (Ed.), Handbook of work group psychology (pp. 53-75). Chichester: Wiley.

Kanter, R. (1977). Men and Women of the Corporation. New York: Basic Books.

Kogut, B. (2000). The network as knowledge: Generative rules and the emergence of structure. Strategic Management Journal, 21(3), 405-425.

Kogut, B., \& Zander, U. (1992). Knowledge of the firm, combinative capabilities, and the replication of technology. Organization Science, 3(3), 383-397.

Kogut, B., \& Zander, U. (1996). What firms do? Coordination, identity, and learning. Organization Science, 7(5), 502-518.

Langan-Fox, J., Code, S., \& Langfield-Smith, K. (2000). Team mental models: Techniques, methods, and analytic approaches. Human Factors, 42(2), 242-271.

Larkey, L. K. (1996). Toward a theory of communicative interactions in culturally diverse workgroups. Academy of Management Review, 21(2), 463-491.

Lazer, D. M. (2001). The co-evolution of individual and network. Journal of Mathematical Sociology, 25(1), 69108. 
Lazer, D. M. (2002). Information and innovation in a networked world. Paper presented at the 98th Annual Conference of the American Political Science Association, 1-4 September 2002, Boston.

Lenk, K. (1997). Business process reengineering in the public sector. In J. M. Taylor, T. M. Snellen \& A. Zuurmond (Eds.), Beyond BPR in Public Administration : Institutional Transformation in an Information Age (pp. 151 - 163). Amsterdam: IOS Press.

Levesque, L. L., Wilson, J. M., \& Wholey, D. R. (2001). Cognitive divergence and shared mental models in software development project teams. Journal of Organizational Behavior, 22, 135-144.

Lewin, K. (1948). Resolving Social Conflicts: Selected Papers on Group Dynamics. New York: Harper.

Lindenberg, S. (1997). Grounding groups in theory: Functional, cognitive, and structural interdependencies. Advances in Group Processes, 14, 281-331.

Lynn, L. E. (1996). Public Management as Art, Science, and Profession. Chatham, NJ: Chatham House Publishers, Inc.

March, J. G. (1991). Exploration and exploitation in organizational learning. Organization Science, 2(1), 71-87.

March, J. G., \& Simon, H. A. (1958). Organizations. New York: John Wiley and Sons.

Mathieu, J. E., Heffner, T. S., Goodwin, G. F., Salas, E., \& Cannon-Bowers, J. A. (2000). The influence of shared mental models on team process and performance. Journal of Applied Psychology, 85(2), 273-283.

McDermott, R. (1999). Why information technology inspired but cannot deliver knowledge management. California Management Review, 41(4), 103-117.

McPherson, J. M., Popielarz, P. A., \& Drobnic, S. (1992). Social networks and organizational dynamics. American Sociological Review, 57(2), 153-170.

Miles, M. B., \& Huberman, A. M. (1994). Qualitative Data Analysis: An Expanded Sourcebook (2nd ed.). Thousand Oaks, CA; London: Sage.

Mohammed, S., \& Dumville, B. C. (2001). Team mental models in a team knowledge framework: Expanding theory and measurement across disciplinary boundaries. Journal of Organizational Behavior, 22, 89-106.

Monge, P. R., \& Contractor, N. (2003). Theories of Communication Networks. New York: Oxford University Press.

Nahapiet, J., \& Ghoshal, S. (1998). Social capital, intellectual capital, and the organizational advantage. Academy of Management Review, 23(2), 242-266.

National Performance Review. (1993). Creating a Government that Works Better and Costs Less: Report of the National Performance Review. New York: Times Books.

Nault, B. R. (1998). Information technology and organization design: Locating decisions and information. Management Science, 44(10), 1321-1335.

Nelson, R. R., \& Winter, S. G. (1982). An Evolutionary Theory of Economic Change. Cambridge, MA: Belknap Press.

Osborne, D., \& Gaebler, T. (1992). Reinventing Government: How the Entrepreneurial Spirit is Transforming the Public Sector. Reading, MA: Addison-Wesley.

Osterloh, M., \& Frey, B. (2000). Motivation, knowledge transfer, and organizational forms. Organization Science, 11(5), 538-550.

Perloff, R. M. (1993). The Dynamics of Persuasion. Hillsdale, NJ: Erlbaum.

Podolny, J. M., \& Page, K. L. (1998). Network forms of organization. Annual Review of Sociology, 24, 57-76.

Poppo, L. (1995). Influence activities and strategic coordination: Two distinctions of internal and external markets. Management Science, 41(12), 1845-1859.

Powell, W. W. (1990). Neither market nor hierarchy - network forms of organization. Research in Organizational Behavior, 12, 295-336. 
Reed, R., \& DeFillippi, R. J. (1990). Causal ambiguity, barriers to imitation, and sustainable competitive advantage. Academy of Management Review, 15(1), 88-102.

Reinermann, H., Fiedler, H., Grimmer, K., Lenk, K., \& Traunmüller, R. (Eds.). (1988). Neue Informationstechniken. Neue Verwaltungsstrukturen? Heidelberg: v. Decker und Müller.

Richards, D. (2001). Coordination and shared mental models. American Journal of Political Science, 45(2), 259276.

Roberts, J. (2000). From know-how to show-how? Questioning the role of information and communication technologies in knowledge transfer. Technology Analysis \& Strategic Management, 12(4), 429-443.

Rouse, W. B., \& Morris, N. M. (1986). On looking into the black box - prospects and limits in the search for mental models. Psychological Bulletin, 100(3), 349-363.

Rulke, D. L., \& Galaskiewicz, J. (2000). Distribution of knowledge, group network structure, and group performance. Management Science, 46(5), 612-625.

Scharf, M. C. (2003). Exploration and Exploitation: Toward a Theory of Knowledge Sharing in Digital Government Projects. Unpublished Dissertation, University of St. Gallen, St. Gallen.

Schedler, K. (1995). Ansätze einer wirkungsorientierten Verwaltungsführung. Bern, Stuttgart, Wien: Haupt.

Schedler, K. (1998). Blowing the Alphorn: Financial management reforms in Switzerland. In O. Olson, J. Guthrie \& C. Humphrey (Eds.), Global Warning! Debating International Developments in New Public Financial Management (pp. 276 - 303). Oslo: Cappelen Akademisk Forlag.

Schedler, K., \& Scharf, M. C. (2001). Exploring the interrelations between e-government and the new public management. In B. Schmid, K. Stanoevska-Slabeva \& V. Tschammer (Eds.), Towards the E-Society: ECommerce, E-Business, and E-Government (pp. 775-788). Boston: Kluwer Academic Publishers.

Schedler, K., \& Summermatter, L. (2002). Was treibt das eGovernment? In D. Spahni (Ed.), eGovernment 2 Perspektiven und Prognosen. Bern, Stuttgart, Wien: Haupt.

Schein, E. H. (1980). Organizational Psychology (3rd ed.). Englewood Cliffs, NJ: Prentice-Hall.

Schumpeter, J. A. (1934). The Theory of Economic Development. Cambridge, MA: Harvard University Press.

Schwandt, T. A. (2000). Three epistemological stances for qualitative enquiry: Interpretivism, hermeneutics, and social constructionism. In N. K. Denzin \& Y. S. Lincoln (Eds.), Handbook of Qualitative Research (2nd ed.). Thousand Oaks, CA: Sage.

Sherif, M. (1936). The Psychology of Social Norms. New York: Harper.

Simon, H. A. (1981). The Sciences of the Artificial (2nd ed.). Cambridge, MA: MIT Press.

Spender, J. C., \& Grant, R. M. (1996). Knowledge and the firm: Overview. Strategic Management Journal, 17(Winter), 5-9.

Strauss, A. L. (1987). Qualitative Analysis for Social Scientists. Cambridge, MA: Cambridge University Press,.

Strauss, A. L., \& Corbin, J. (1990). Basics of Qualitative Research: Grounded Theory Procedures and Techniques. Thousand Oaks: Sage.

Szulanski, G. (1996). Exploring internal stickiness: Impediments to the transfer of best practice within the firm. Strategic Management Journal, 17, 27-43.

Szulanski, G. (2000). The process of knowledge transfer: A diachronic analysis of stickiness. Organizational Behavior and Human Decision Processes, 82(1), 9-27.

Toonen, T. A. J., \& Raadschelders, J. C. N. (1997, April 5-8, 1997). Public sector reform in Western Europe. Paper presented at the Conference on Comparative Civil Service Systems, Indiana University, Bloomington.

Tsagarousianou, R., Tambini, D., \& Bryan, C. (1998). Cyberdemocracy: Technology, Cities and Civic Networks. London: Routledge. 
Tsai, W. P. (2002). Social structure of "coopetition" within a multiunit organization: Coordination, competition, and intraorganizational knowledge sharing. Organization Science, 13(2), 179-190.

Uzzi, B. (1997). Social structure and competition in interfirm networks: The paradox of embeddedness. Administrative Science Quarterly, 42(1), 35-67.

van de Ven, A. H. (1976). A framework for organization assessment. Academy of Management Review, 1(1), 64-78.

von Hippel, E. (1994). 'Sticky information' and the locus of problem solving: Implications for innovation. Management Science, 40(4), 429-439.

Wasserman, S., \& Faust, K. (1994). Social Network Analysis. Cambridge, MA: Cambridge University Press.

Watson, W. E., Kumar, K., \& Michaelsen, L. K. (1993). Cultural diversity's impact on interaction process and performance - comparing homogeneous and diverse task groups. Academy of Management Journal, 36(3), 590-602.

Weber, M. ([1921]1968). Economy and Society (G. Roth \& C. Wittich, Trans. Vol. 1-3). New York: Bedminster Press.

Weiss, L. M. (1998). Collection and Connection: Rationalized and Embedded Knowledge in Knowledge-Intensive Organizations. Unpublished Dissertation, Harvard University, Cambridge, MA.

Williams, M. (2001). In whom we trust: Group membership as an affective context for trust development. Academy of Management Review, 26(3), 377-396.

Williamson, O. E. (1975). Markets and Hierarchies: Analysis and Anti-Trust Implications. New York: Free Press.

Yin, R. K. (1994). Case Study Research: Design and Methods (2nd ed.). Thousand Oaks: Sage.

Zander, U. (1991). Exploiting a Technological Edge - Voluntary and Involuntary Dissemination of Technology. Stockholm: Institute of International Business.

Zander, U., \& Kogut, B. (1995). Knowledge and the speed of the transfer and imitation of organizational capabilities: An empirical test. Organization Science, 6(1), 76-92. 


\section{Footnotes}

${ }^{\mathrm{i}}$ It should be noted that while bureaucracies rely on rationalized knowledge, it certainly is not the only type of knowledge that has been observed in a bureaucracy. Tacit knowledge plays an important role in bureaucratic decisionmaking (cf. Blau, 1963) which Max Weber ([1921]) referred to as “Dienstwissen” (knowledge on the job).

${ }^{i i}$ Much of the literature discussed in this chapter has its origins in research on teams, i.e. a group with clearly defined membership whose members are interdependent to perform a specific task and which operates in the context of a larger organization (Alderfer, 1977). I will be using the broader notion of group in this study to accommodate work groups whose boundaries are not clearly defined.

iii This is not true for the Swiss cases, where one-line budgets have been adopted in the course of NPM projects.

${ }^{\text {iv }}$ In DGP 2, the project manager came from the private sector, whereas in DGP 3 the project manager had previously worked in a different agency of the same government. 
Table 1

Case overview

\begin{tabular}{|c|c|c|c|c|c|c|c|c|}
\hline Name & Interviews & Location & $\begin{array}{l}\text { Project } \\
\text { start }\end{array}$ & Project objectives & Portal launch & Project initiation & $\begin{array}{l}\text { Description of project } \\
\text { group }\end{array}$ & Status (2002) \\
\hline DGP 1 & 6 & $\mathrm{CH}$ & 2001 & $\begin{array}{l}\text { Life events portal } \\
\text { Integration of IT } \\
\text { infrastructure } \\
\text { Incorporation of } \\
\text { existing projects }\end{array}$ & $\begin{array}{l}2003 \\
\text { (expected) }\end{array}$ & $\begin{array}{l}\text { State government appointed } \\
\text { the state secretary to explore } \\
\text { the situation of DG in the state } \\
\text { and draft a project proposal }\end{array}$ & $\begin{array}{l}\text { Project manager, many } \\
\text { loosely connected } \\
\text { project members } \\
\text { Affiliation: State } \\
\text { chancellery }\end{array}$ & $\begin{array}{l}\text { Expanding } \\
\text { (conception) }\end{array}$ \\
\hline DGP 2 & 5 & $\mathrm{CH}$ & 2000 & $\begin{array}{l}\text { Life events portal } \\
\text { Intranet } \\
\text { Optimization of } \\
\text { internal processes } \\
\text { Implementation of } \\
\text { partial projects }\end{array}$ & $\begin{array}{l}2003 \\
\text { (expected) }\end{array}$ & $\begin{array}{l}\text { State government hired } \\
\text { consultant to assess the } \\
\text { potential of DG as part of the } \\
\text { ongoing government reform }\end{array}$ & $\begin{array}{l}\text { Project manager, core } \\
\text { team of four } \\
\text { Affiliation: State } \\
\text { chancellery }\end{array}$ & $\begin{array}{l}\text { Ongoing } \\
\text { (implemen- } \\
\text { tation) }\end{array}$ \\
\hline DGP 3 & 8 & US & 2000 & $\begin{array}{l}\text { Intentions-based } \\
\text { portal } \\
\text { Common IT } \\
\text { infrastructure } \\
\text { Implementation of } \\
\text { partial projects }\end{array}$ & 2002 & $\begin{array}{l}\text { Governor appointed a public- } \\
\text { private task force to develop a } \\
\text { strategic plan and } \\
\text { implementation roadmap }\end{array}$ & $\begin{array}{l}\text { Project manager, core } \\
\text { team of five } \\
\text { Affiliation: State IT } \\
\text { department }\end{array}$ & $\begin{array}{l}\text { Ongoing } \\
\text { (implemen- } \\
\text { tation) }\end{array}$ \\
\hline DGP 4 & 10 & US & 1998 & $\begin{array}{l}\text { Coordination of } \\
\text { applications, } \\
\text { infrastructure, and } \\
\text { policy }\end{array}$ & 2000 & $\begin{array}{l}\text { Legislature appointed a board } \\
\text { to explore and coordinate DG } \\
\text { initiatives, which resulted in a } \\
\text { roadmap and a strategic plan }\end{array}$ & $\begin{array}{l}\text { Various project } \\
\text { managers, members of } \\
\text { project group loosely } \\
\text { connected } \\
\text { Affiliation: State IT } \\
\text { department }\end{array}$ & $\begin{array}{l}\text { Established } \\
\text { (running) }\end{array}$ \\
\hline
\end{tabular}


Figure 1

Causal model of knowledge sharing in DGPs

Structure Interaction Content

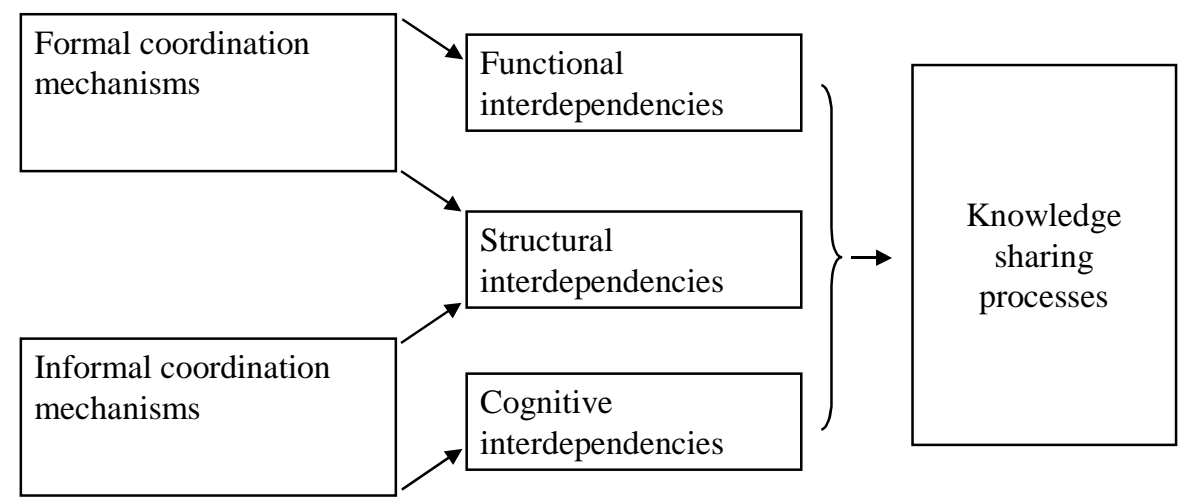

Figure 2

Density of ties in knowledge networks
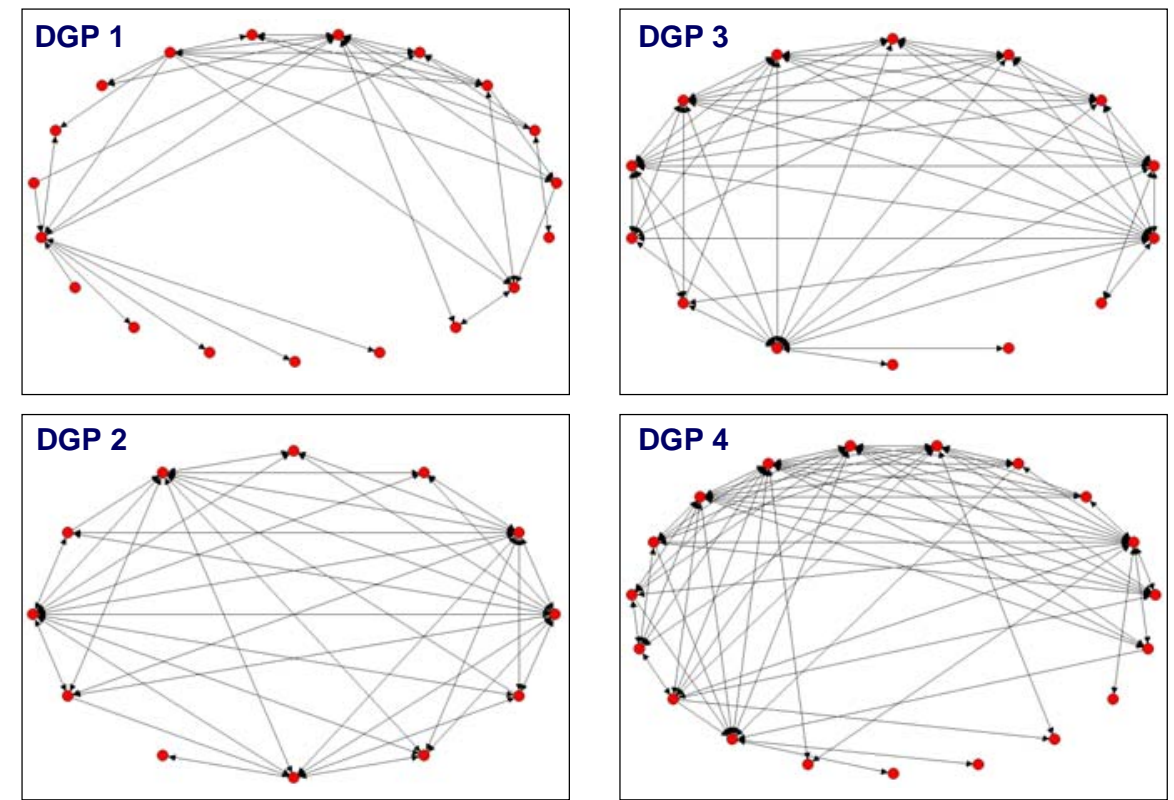

Figure 3 
Functional subdivision of knowledge networks
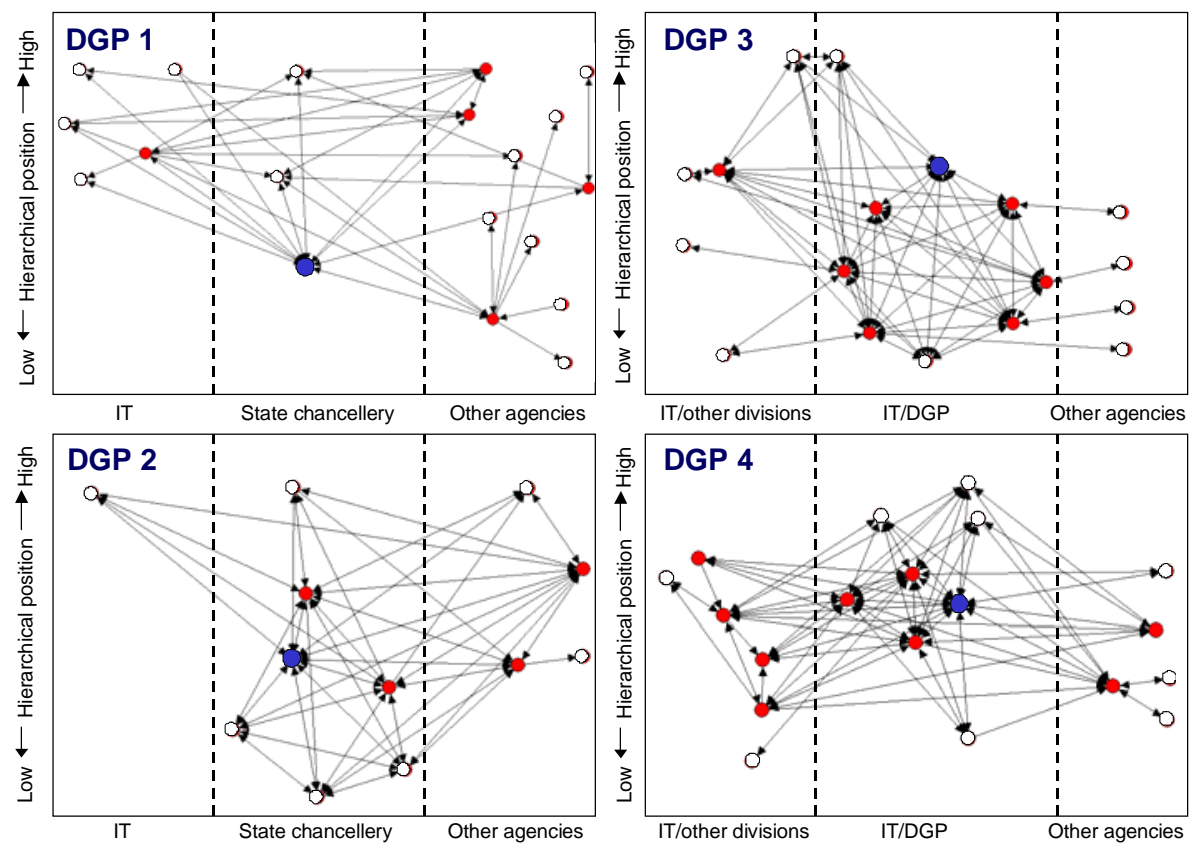

Figure 4

Exploration and exploitation of knowledge in DGPs

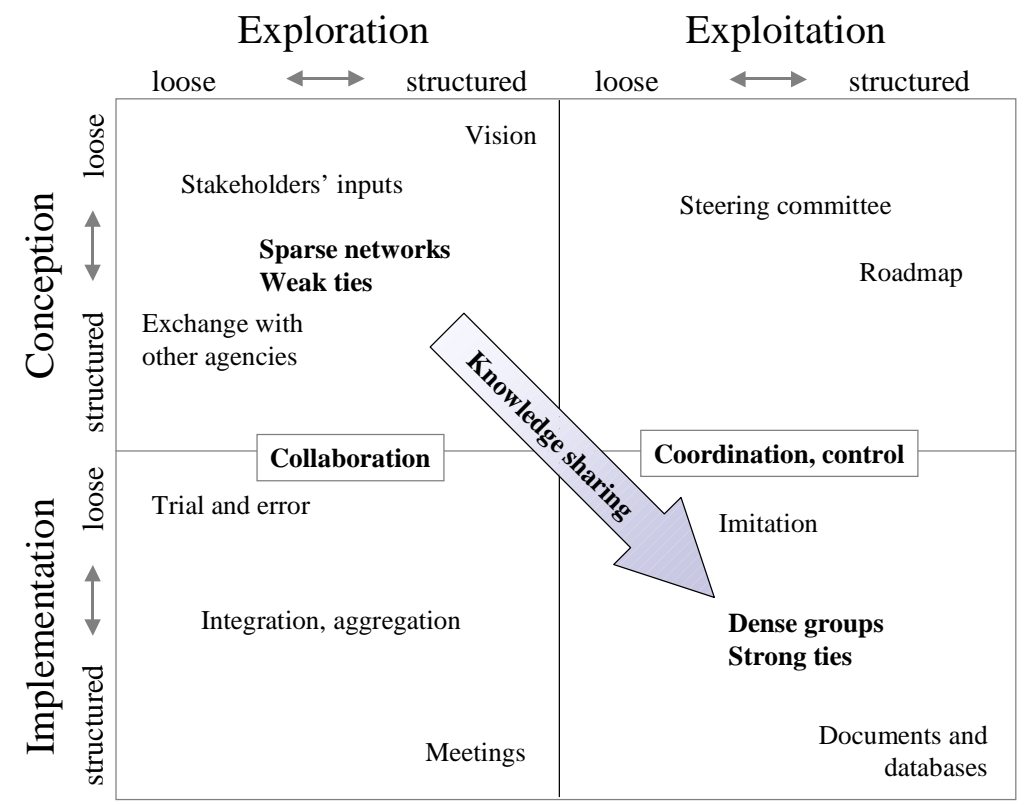

